\title{
THE IMPACT OF THE PANDEMIC COVID-19 ON THE STATE OF INTERNATIONAL POLITICS AND SECURITY
}

\author{
Dr. Loc Thi Thuy ${ }^{* 1}$ 《 iD \\ ${ }^{* 1}$ Vietnam Institute of Americas Studies, Vietnam Academy of Social Sciences, Hanoi, Vietnam
}

DOI: https://doi.org/10.29121/granthaalayah.v8.i12.2020.2681

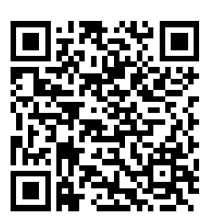

Article Type: Research Article

Article Citation: Dr. Loc Thi Thuy. (2020). THE IMPACT OF THE PANDEMIC COVID-19 ON THE STATE OF INTERNATIONAL POLITICS AND SECURITY. International Journal of Research GRANTHAALAYAH, 8(12), 238-246. https://doi.org/10.29121/granthaa layah.v8.i12.2020.2681

Received Date: 03 December 2020

Accepted Date: 31 December 2020

Keywords:

The State of International Politics and Security Impact of The Covid-19 Pandemic U.S - China Competition

\begin{abstract}
From the beginning of the year 2020 until now, the Covid-19 pandemic has heavily, deeply and comprehensively impacted the state of international politics and security in both positive and negative directions. On one hand, the pandemic has encouraged nations to strengthen cooperation in order to effectively deal with the risks that it brought; on the other hand, it has contributed to a rise in competition as well as opposition between countries and global powers alike, especially between the U.S. and China, in multiple politics and security-related issues. In the coming times, the state of international politics and security is predicted to witness many changes, especially in the context where the U.S. is highly expected to adjust its policies. For this text, the writer will place an emphasis on providing in-depth analysis on the negative impacts of the Covid-19 pandemic on the state of international politics and security, and therefore provide commentary on the trends of the state of international politics and security in the coming times.
\end{abstract}

\section{INTRODUCTION}

It can be stated that the Covid-19 pandemic has greatly impacted the state of international politics and security, both positively and negatively, even though the impact is still chiefly negative. According to the figures provided by the World Health Organization (WHO) on November 28 th 2020 , the total number of Covid-19 cases is $60.3 \mathrm{~m}$ globally, with $1.42 \mathrm{~m}$ having perished (VTV News, 2020a). This has not only brought the world's economic growth rate from 3\% (2019) to $-4.9 \%$ (2020) (VTV News, 2020b), but also affected the international politics and security outlook through increasing nationalism, competition of global powers such as the U.S.-China rivalry, and unconventional security issues such as nuclear security, terrorism, separatism and ultra-nationalism.

\section{CONTENT}

\subsection{RESEARCH PURPOSE}

(i) Provide analysis to clarify the impact of the Covid-19 pandemic on the state of international politics and security; (ii) Evaluate the impact of the Covid-19 pandemic on the state of international politics.

(C) 2020 The Author(s). This is an open access article distributed under the terms of the Creative Commons Attribution License, which permits unrestricted use, distribution, and reproduction in any medium, provided the original author and source are credited. 


\section{Dr. Loc Thi Thuy}

\subsection{RESEARCH METHODOLOGY}

The writer has used methods of logical analysis on history, international relations and international politics on the impact of the developments of the Covid-19 pandemic on the state of international politics and security, through analyzing issues that will impact the state of international politics and security, in order to maintain the scientific and logical integrity, and be systematically sound. To maintain the scientific principles of politics and international affairs, the writer has also used regional studies, international studies and political studies to analyze the state of international politics and security in the foreseeable future.

\subsection{RESULTS OF ANALYSIS AND RESEARCH}

\subsubsection{ON THE STATE OF INTERNATIONAL POLITICS}

The state of international politics witness complex and unpredictable developments under the negative impact of the Covid-19 pandemic. To be specific:

Firstly, while the U.S.-China rivalry continues to intensify globally, the rivalry itself will trend from bilaterally to multilaterally.

In 2020, due to the negative impact of the Covid-19 pandemic, the U.S.-China rivalry has gone from one in trade and technology to a comprehensive rivalry across all dimensions (Andy Zelleke, 2020). In the coming times, even if Mr. Biden becomes the new President of the U.S., the rivalry will continue to intensify, especially as both the mainstream politics and public opinion of either country considering countering the other to be the driving force in each country's policies. That the U.S. will not be straying from this trajectory regardless of who its next leader is is supported by the fact that while the U.S. is undergoing the Trump-Biden transition of power, China has thoroughly exploited the gaps in the U.S.'s power to successfully sign with 15 Asian and Pacific countries the RCEP Treaty (Eleanor Albert, 2020). With the signing of this Treaty, China has initially succeeded in breaking through the political and economic blockade (Vietnam News Agency, 2020c) that the Trump administration has imposed on this country since 2017, by making the RCEP countries China's domestic export markets and importers for Chinese microchips, avoiding the disruption of China's supply chain that was caused by the U.S.'s economic sanctions.

Until January 20 2021 (the U.S. President's inauguration date), both the U.S. and China will put forth their objectives and ambitions for their global position, especially in the Asia-Pacific region, which is considered by both countries a growth hub and crucial region for maintaining their status as global powers. To be specific:

As for China, it is taking advantage of the power vacuum left by the U.S. to gradually realize its political ambitions, including negotiating and joining the CPTPP ${ }^{1}$, facilitating the signing of FTAs with Japan and China (Yen-Chiang Chang and Shuo Li, 2020), establishing a new political framework in East Asia based on the "New Asia-Pacific region" idea that was put forward by Chairman Xi at the Beijing APEC (2014), and facilitating its "dual circulation" (domestically and internationally) to control 3 of its important markets in ASEAN, EU and Japan (Zoey Zhang, 2020). As remarked by Chairman Xi, controlling these markets will help China avoid a state of being politically and diplomatically isolated by the U.S., while preventing a disruption in China's supply chain in case the new U.S. administration decides to uphold the economic sanctions levied by the Trump administration (Bethany AllenEbrahimian, 2020).

As for the U.S., in order to counter the aforementioned ambitions, the Trump administration has demanded that the new administration fulfill the objective of not overturning the anti-China policies that have been created in the past 4 years (Eamon Barrett, 2020). To realize this vision, the new U.S. administration has pledged to bring the U.S. back to the negotiation table for $\mathrm{CPTPP}^{2}$, but this time with the participation of allied and partner nations outside the current 11 member nations to curb China's ambitions (Vietnam News Agency, 2020d). At the same time, it is open to negotiation for RCEP alongside India's participation (Alex Fang, 2020). The reappearance of the U.S. in these two partnerships is expected to contribute to restoring the U.S.-China power balance in the region.

\footnotetext{
${ }^{1}$ Why China is considering joining the CPTPP, at https://news.cgtn.com/news/2020-11-21/Why-China-is-considering-joining-theCPTPP-VAShPDDIPu/index.html, on 21 November, 2020

${ }^{2}$ US President Joseph Biden: time for a "reset" on trade?, at http://asiantradecentre.org/talkingtrade/us-president-joseph-biden-time-fora-reset-on-trade, on November 9, 2020
} 
The Impact of The Pandemic Covid-19 on the State of International Politics and Security

Secondly, the Covid-19 pandemic has deepened the existing conflicts and led to a rise in nationalism in many European countries.

The Covid-19 pandemic has contributed to increasing nationalism and nationalist movements in many regions in the world, especially Europe. In the recent past, the immigration crisis of 2014-2016 has divided Europe into 3 groups of countries, one being in favor of immigration (Germany, France), one being neutral toward immigration (Italy, Spain, Greece, Portugal and one being against immigration (the UK, Hungary, Poland, Czech Republic). The direct consequences of this division were stark, as the UK withdrew from the European Union via Brexit (2016) while the Eastern European countries closed their borders ${ }^{3}$.

However, the impact of immigration policies is not as significant as that of the Covid-19 pandemic. This is because according to the WHO's report on November 28th, Europe has overtaken the U.S. as the region with the second most Covid-19 cases, behind Latin America, with 13.5m people affected and over 400,000 dead (VTV News, 2020 e). Europe's economy has been affected as a result, losing economic growth by up to 7\%, with some countries suffering growth losses between 9 and 12\% (Vietnam News Agency, 2020e) such as France and the UK (its most serious economic downturn in 300 years). This aforementioned economic hardship has heightened the complications in Europe's socio-political condition, marked by long-standing conflicts related to race, ethnicity, territory and separatism that are now having the opportunity to resurface. In the UK, Nicola Sturgeon's Scottish National Party is strengthening efforts to seek international support for Scotland's separation from the UK and rejoining the EU (Ciara Nugent, 2020). In Spain, the leaders of Catalan and Basque increasingly demand independence and separation from Spain (David Gardner, 2019) while in Belgium, the French-speaking region of Wallonia is also pushing for a referendum on its independence (David Walsh, 2020).

In addition, the pandemic has played a role in increasing the wealth inequality between Western and Eastern European nations within the $\mathrm{EU}^{4}$, as the Western European nations are more economically potent and therefore better equipped to deal with the Covid-19 pandemic, while their Eastern counterparts are middling nations that have been transitioning from Soviet-style planned economies to free market economies and therefore less financially or economically capable of addressing both the illegal immigration issue and the Covid-19 pandemic. On top of that, with the economies of the 27 EU nations being on protracted lockdown and becoming more closed as a result, Eastern Europe has become more impoverished, leading to the rise of nationalism. This is evident in the advent of nationalist leaders who demand autonomy and refuse to follow the EU's regulations, especially in issues related to democracy, human rights and law such as Viktor Orban, Hungary's Prime Minister, Andrzej Duda, Poland's President or Milos Zeman, Czech Republic's President. These leaders have publicly rebuked the EU's slow action in disbursing a US $\$ 500$ bn bailout for its members in May this year (Daniel Boffey, 2020), voiced their support for China through the 17+1 Group (China and 17 Eastern European countries) and received financial and medical support packages to help China promote its "Chinese model" and "Chinese solution" right in the middle of Europe (Ivana Karásková, 2020). These actions have not only worsened the division between EU countries in the West and those in the East, but also generated opportunities for the U.S. and China to exploit and turn Europe into another battleground for political influence. The U.S. Secretary of State Pompeo's visits to the UK and Denmark in July 2020 to call for an establishment of an alliance of Western democracies against Huawei ${ }^{5}$ and "Chinese-style" authoritarian dictatorship are a proof of this.

The Covid-19 pandemic is predicted to last long and drive the nationalist movement in Europe along the following directions: (1) Hastening the struggle for independence and birth of new independent nations such as Scotland, while Northern Ireland rejoins the Republic of Ireland; (2) radicalizing Eastern European nations in the EU, and polarizing the EU into an "open" Europe led by Germany next to a "closed" Europe led by Hungary that leans toward Russia and China's spheres of influence; (3) creating disagreements between the U.S. and EU in issues related to human rights and democracy, allowing Turkey to cause instability in Southeastern Europe and East Mediterranean Sea; (4) accelerating the division between the UK and EU where the EU restores ties with Russia while the UK strengthens ties with the U.S., leading to a EU-Russia and UK-U.S. rivalry in Europe.

Thirdly, the Covid-19 pandemic creates new political powers outside the U.S. and China.

\footnotetext{
${ }^{3}$ Responding to the migrant crisis: Europe at a Juncture, at https://www.iris-france.org/wp-content/uploads/2016/07/RAN-Respondingto-the-Migrant-Crisis-FINAL.pdf, on June 2016

${ }^{4}$ European Economic Forecast, at https://ec.europa.eu/info/sites/info/files/economy-finance/ip125_en.pdf, on May 2020

${ }^{5}$ Pompeo says to visit Britain after Huawei ban decision, at https:/www.deccanherald.com/international/world-news-politics/pompeosays-to-visit-britain-after-huawei-ban-decision-861787.html, on July 16, 2020

International Journal of Research -GRANTHAALAYAH 


\section{Dr. Loc Thi Thuy}

In 2020, the Covid-19 pandemic has contributed to the presence of new political centers. These include the Egyptian administration led by President Abdel Fattah El-Sisi, who have taken advantage of the power vacuum left by the U.S. to extend political influence to Egypt's neighbors of Libya, Sudan and Ethiopia through counter-terrorism and the Grand Ethiopian Renaissance Dam (Hana Sabah and Hamza Hendawi, 2020). Meanwhile, in the Middle East, via the "New Ottoman Policy" (Avatkov Vladimir Alekseevich, 2018), Turkey has increased its political, military and security involvement in the South of the Caucasus Mountains, East Mediterranean Sea, North Africa, Central Asia and Syria in order to realize its goal of becoming a regional power (Eugene Chausovsky, 2020), at the same time challenging the presence of the U.S., Russia and the EU in Southeaster Europe and the Black Sea (Gonul Tol and Rauf Mammadov, 2020). In Latin America, the Mexican government has expanded its sphere of influence to left-leaning Latin American countries with the "Establishing the new Leftist coalition in Latin America" project, having the participation of 6 countries in Mexico, Cuba, Nicaragua, Uruguay, Argentina and Bolivia. In the coming times, this coalition is expected to grow with the participation of others such as Brazil, Ecuador and certain Carribean countries. This will create a new Leftist alliance in Latin America to offset the U.S.'s influence. And as for the post-Soviet bloc, Russia has increased its influence and actively sought involvement in hot spots such as Nagorno-Karabakh (Anders Aslund, 2020), East Ukraine, Belarus and Central Asian countries in the Commonwealth of Independent States to reaffirm its status as the region's leading power.

In the foreseeable future, this trend is expected to intensify, especially as the U.S. has a new administration and will focus on addressing domestic issues, chiefly the Covid-19 pandemic and economic recession. China will also focus its attention on economic development through the "dual circulation" policy, causing the state of international politics to turn from a "monopole" or "single superpower among multiple powers" status quo into a new international order with the presence of many regional powers in which the roles of countries such as Russia, Turkey, Mexico and Japan will be looked at with more consideration.

Fourthly, the political outlook in Latin America is gradually turning from right-leaning to left-leaning.

The negative impacts of the Covid-19 pandemic have pushed the socio-economic condition in Latin American countries to the brink. According to WHO figures on November 29th, there were 16 million Covid-19 cases in Latin America, with over 500,000 dead, and 3 (Brazil, Mexico and Peru) out of 35 countries and territories had over 1.5 million affected (VTV News, 2020f). As a result, Latin America's economy declined by 6\% (2020), representing a loss in GDP of over US $\$ 1000$ bn compared to 2019 , with over US $\$ 200$ bn accounted for by the tourism sector (Vietnam News Agency, 2020f).

These aforementioned economic difficulties have allowed leftist political forces in the region an opportunity for resurgence after a period of floundering from 2013 to 2019. This was expressed in the victory of the Movement for Socialism Party (MAS) of former President Evo Morales against the U.S.-friendly sitting President Jeanine Anez in the Presidential Election of October 18 th 2020 (Jihan Abdalla, 2020). With a population of under 12 million $^{6}$, Bolivia is not a significant power in the region but MAS's victory as a left-leaning party with a history of 14 years in power has contributed to turning the state of Latin American politics from a right-leaning one to a left-leaning one, weakening the role that the U.S. and the Lima Group play as a result. The leftist movement in Latin America has also witnessed change in that the apparent leading power is now Mexico, long considered a U.S. ally, instead of the U.S.-opposing Venezuela. In addition, Mexico through the leftist movement wants to realize the idea of establishing a new democratic and modern left-wing coalition in Latin America that still maintains cooperation with the U.S. instead of the hardline anti-U.S. stance that was taken by the ALBA Group (Ash Narain Roy and Shimone Jaini, 2020).

These issues have helped to predict a leftward change in Latin America's political outlook, but this brand of leftism should be understood as a movement that calls for democratization and diversification of government type, not a movement that calls for "Socialism in the $21^{\text {st }}$ century" per the ALBA Group.

\subsubsection{ON THE STATE OF INTERNATIONAL SECURITY}

Apart from its political implications, the Covid-19 pandemic also deeply affects the state of international security, and turns the security outlook in the following directions:

Firstly, the Covid-19 pandemic has increased terrorism and religious extremism in multiple areas in the world.

${ }^{6}$ Bolivia Population, at https://www.worldometers.info/world-population/bolivia-population/, on December 4, 2020. International Journal of Research -GRANTHAALAYAH 
Terrorism and religious extremism are not new topics of public discourse but have since become intensified due to the pandemic's negative impacts in poverty, economic depression and diseases.

In Europe, international terrorists have used the French's government raiding of 356 mosques, deportation of 428 Islamic extremists and breaking up of 50 Islamic extremist political movements (Vietnam News Agency, 2020g) to carry out many anti-French terrorist acts, most notably the beheading of Samuel Paty (Caroline Pailliez, 2020). This event is predicted to be the precursor of many intensifying terrorist acts by Islamic extremist groups such as the ISIL or Al-Qaeda in Europe in the coming times, especially as the leaders of Islamic countries such as Saudia Arabia, Pakistan and Indonesia have expressed their disapproval of the French President Macron's remarks in Samuel Paty's funeral, having found them Islamophobic (10/2020).

In the South of the Caucasus Mountains, Turkey has extensively taken advantage of its status as Azerbaijan's ally to bring 5000 terrorist fighters from the Free Syrian Army to take action against Armenia in Karabakh (Raja Abdulrahim, 2020), but in fact is to expand the influence of terrorism in Russia.

In North Africa and the Middle East, terrorist groups have exploited the power vacuum left by the U.S. and EU to expand their operations in Libya, Somalia, Egypt and Syria, in their attempt to realize Osama bin Laden's vision of an Islamic Caliphate that stretches from the Mediterranean Sea to Mindanao in the Philippines (Vietnam News Agency, 2020h). Bin Laden's ambition was in a sense similar to the democratization policy that the George W. Bush administration put forward in 2005 to democratize Islamic nations from Morocco to Philippines (Vietnam News Agency, 2020i). This policy is expected to be taken once again by the new U.S. administration.

The aforementioned issues are predicted to create opportunities for terrorism and Islamic extremism to develop, especially as the Covid-19 pandemic continues to develop and poverty and inequality continue to rise in many countries over the world, mainly underdeveloped and developing ones.

The Covid-19 pandemic has also created a new international security hot spot in the East Mediterranean Sea. As Turkey's Erdogan administration wants to shift public opinion's focus away from the negative domestic impact of the pandemic (Turkey has 1.3 million affected by Covid-19, with over 50,000 dead and its economy is expected to lose US $\$ 400$ bn compared to 2019) (Edam, 2020), Turkey has accelerated the expansion of its influence in the East Mediterranean Sea by creating military and security interventions, such as with Libya in counter-terrorism or Greece in the S-400 missiles problem, strengthening Erdogan's power domestically. Other well-known hot spots such as the East Vietnam Sea, Taiwan and North Korea continue to stay relevant due to the conflicts between nations in and outside the region (mainly between the U.S. and China) that want to vie for status and influence in East Asia.

Secondly, the Covid-19 pandemic has intensified unconventional security issues such as diseases, poverty and food security.

Prior to the pandemic, unconventional security issues such as diseases, poverty and food security were present but not urgent on a global scale. With the outbreak of Covid-19, these issues have become severe. According to FAO's reports in November 2020, the Covid-19 pandemic has created shortages of food and medical supply for 800 million people worldwide in 2020 (VTV News, 2020b). In particular, 20 million out of 34 million people in Venezuela are suffering from hunger (Vietnam News Agency, 2020a). In the United States, up to 60 million people are experiencing food shortage. In France, 12 million out of 64 million people are experiencing food shortage. There are 200 million that are in need of food out of 600 million people in Latin America, while this figure in Africa is 500 million out of 1.3 billion people. These figures might even rise to 1.5-2 billion people in 2021 according to projections (VTV News, 2020c), if the world is unable to develop a vaccine or medication to prevent and cure this pandemic.

The current situation can deteriorate ${ }^{7}$ as several major food exporters such as Russia, the U.S. and Thailand have cut down on their export volume in order to maintain food security. Meanwhile, countries like China ramp up their efforts to buy and accumulate grain (estimated 280 million tonnes in 2020) (VTV News, 2020d) to realize their objective of maintaining domestic food security and raising political status internationally.

These aforementioned issues are expected to continue to develop in the foreseeable future and polarize the world's security in that China will become a major recipient of the benefits, while the U.S. and the Western world will be disadvantaged. As a result, China will be steps closer to its goal during and after the Covid-19 pandemic, such goal being catching up with the U.S., Russia and the West economically and militarily, and as a result realizing the objective of becoming an economically strong, politically stable and militarily significant nation by 2035 , the same

${ }^{7}$ Food security and Covid-19, at https:/www.worldbank.org/en/topic/agriculture/brief/food-security-and-covid-19, on Octorber 15, 2020. 


\section{Dr. Loc Thi Thuy}

year that China expects to be a modern industrialized nation before it becomes a full-fledged global superpower in 2049 (David Dollar, Yiping Huang, Yang Yao, 2020).

Thirdly, the Covid-19 pandemic has led to a rise in nuclear security-related conflicts between the U.S., Russia and China.

The Covid-19 pandemic has contributed to worsening the conflicts related to nuclear security between the U.S., Russia and China. As the pandemic has caused all three economies to decline significantly, with the U.S. losing US $\$ 2000 \mathrm{bn}$ in its GDP value, Russia US\$300bn, and China US\$1000bn in particular (Vietnam News Agency, 2020k), their defence spending has been directly affected, especially in the maintenance of their gigantic nuclear stockpile (The U.S. has 7200 nuclear warheads and 1000 ballistic missiles, Russia has 6800 nuclear warheads and 1000 ballistic missiles, and China has 300 nuclear warheads and 3000 ballistic missiles (Ankara, 2018)). In addition to this, concerns regarding China's nuclear program and Russia's violations of the INF Treaty and Open Sky Treaty have resulted in the Trump administration withdrawing its participation in 2020 (Peter Jones, 2020). This and the disagreements in the reduction of Russia and the U.S.'s nuclear arsenals to 1000 nuclear warheads each by 2030 have led to difficulties in the Russo-American relationship regarding negotiation of the New START treaty and INF (Richard Sokolsky, 2020).

Furthermore, disputes between the U.S. and Russia continue to exist regarding how to bring China to the negotiations for INF and newer nuclear treaties based on the 3+ mechanism (the U.S., Russia and China). While the U.S. consider the participation of Russia and China to be necessary, Russia considers the participation of the UK and France to also be necessary alongside China's. As a result, these three powers' disagreement has intensified around the issue of deploying mid-range missiles carrying nuclear warheads at the border of each respective nation, most notably Russia's Iskander missiles in Kalinigrad against the U.S.'s Patriot missiles in Alaska, Russia's Topol missiles in Siberia, Transbaikalia and Kamchatka against the U.S.'s Patriot missiles in Alaska and China's Long March missiles in Manchuria and Xinjiang.

These aforementioned issues are predicted to continue intensifying in the coming times as the new U.S. administration might seek a tougher stance against Russia in nuclear and geopolitics. Meanwhile, China will want to take advantage of the new U.S. administration's policy of avoiding direct confrontation with China in order to modernize its nuclear arsenal and strengthen its status in Asia's nuclear hot spots of North Korea, Pakistan and Iran as a counterbalance against the U.S.'s power.

\subsubsection{COMMENTARY}

As analyzed above, even though the Covid-19 pandemic has negatively affected the state of international politics and security, cooperation is still largely mainstream in international affairs. This is because since the Treaty of Westphalia of 1648, the world's first international relations treaty ${ }^{8}$, cooperation has been considered necessary in international affairs and the Covid-19 does not disprove this fact.

In the coming times, under the complex and unpredictable current developments of the Covid-19 pandemic, the state of international politics and security is predicted to develop with more emphasis on cooperation than competition. In particular, countries will need to work together to solve the daily issues that are caused by the Covid19 pandemic such as poverty, food security, socio-political unrest and unemployment. This is coincidentally fitting with Mao Zedong's remarks in Quotations from Chairman Mao Tse-tung that the government “is born on a gun's barrel". If the government is to be preserved, the gun (the military) and the pen (the thoughts) are both necessary (Vietnam News Agency, 2018), meaning that in this day and age, nations can only develop when there is cooperation to deal with crucial issues for mankind, ones that the Covid-19 pandemic is an example of. Without cooperation, nations will not be able to escape from decline and other undesirable conditions that have resulted in great divisions in the past, not unlike how the Spanish Flu of 1914-1918 and Great Depression of 1929-1933 have pushed the world to two catastrophic World Wars.

However, the trend of competition will continue to persist alongside cooperation and cause instability in the international politics and security outlook. This is because in the present and foreseeable future, the approach of competition is highly favored by many nationalistic leaders in the world. From their points of view, the instability in the world and regional status quo has created a rare opportunity to realize their political ambitions and

8 The Treaty of Westphalia, at https://www.historytoday.com/archive/months-past/treaty-westphalia, on 10 October 1998. International Journal of Research -GRANTHAALAYAH 
machinations that ultimately serve their nations' self interest. That China successfully signs the RCEP Treaty on November 15 $5^{\text {th }}$ (Eleanor Albert, 2020) and makes reclaiming Taiwan an objective of 2021 (the year of China's completing the first Hundred Year Marathon) (Ehizuelen Michael Mitchell Omoruyi, 2020), Turkey expands its influence in South Caucasus and East Mediterranean Sea, Russia increases its involvement in Central Asia, or the U.S. becomes increasingly involved in the East Vietnam Sea is the clearest evidence for this statement.

\section{CONCLUSION}

It can be stated that the impacts from the Covid-19 pandemic have made the state of international politics and security complex and unpredictable. This complexity is predicted to intensify in the coming times, especially as many global powers seek to take advantage of the opportunity to expand their spheres of influence in politics and security, and affirm their status. With China putting the "dual circulation" policy into effect and the new U.S. administration wanting to re-intervene in different regions and nations via multilateralism, the state of international politics and security will witness many volatile and complicated changes and developments in the future.

\section{SOURCES OF FUNDING}

This research received no specific grant from any funding agency in the public, commercial, or not-for-profit sectors.

\section{CONFLICT OF INTEREST}

The author have declared that no competing interests exist.

\section{ACKNOWLEDGMENT}

None.

\section{REFERENCES}

\section{Vietnamese}

[1] VTV News (2020a), WHO's published figures on the global Covid-19 situation, updated November 29th 2020.

[2] VTV News (2020b), FAO's report on the global poverty situation as a result of the Covid-19 pandemic, updated November 8th 2020.

[3] VTV News (2020c), IMF's projections on the global food shortage situation as a result of the Covid-19 pandemic, updated November 18th 2020.

[4] VTV News (2020d), China improves its food reserve during Covid-19, updated October 30th 2020.

[5] VTV News (2020e), Europe is the region with the second most Covid-19 cases, updated November 28 th 2020.

[6] VTV News (2020f), Latin America is the region with the most Covid-19 cases, updated November 28 th 2020.

[7] Vietnam News Agency (2020a), Venezuela before the U.S.'s pressure, No. 132, May 24th, pg. 26.

[8] Vietnam News Agency (2020b), The new world order, special documentation, No. 256, October 5th, pg. 8.

[9] Vietnam News Agency (2020c), RCEP helps China break through the U.S.'s blockade, No. 312, November 22nd, pg. 2.

[10] Vietnam News Agency (2020d), How China manipulates RCEP, No. 313, ngày November 23rd, pg. 4.

[11] Vietnam News Agency (2020e), Covid-19 and the EU-China relationship (first section), No. 131, May 23rd, pg. 19.

[12] Vietnam News Agency (2020f), Assessing the recovery of the global economy, No. 306, November 16th, pg. 10.

[13] Vietnam News Agency (2020g), Will France find a way out of extremism?, No. 293, November 3rd, pg. 21.

[14] Vietnam News Agency (2020h), The impact of the UAE-Israel agreement on Middle Eastern peace, No. 235, September 6th, pg. 20. 


\section{Dr. Loc Thi Thuy}

[15] Vietnam News Agency (2020i), The impact of the U.S. Presidential election to relations with Iran, No. 293, November 3rd, pg. 17.

[16] Vietnam News Agency (2020k), The new world order, special documentation, No. 256, October 19th, pg. 10.

[17] Vietnam News Agency (2018), America's policy toward China: from Henry Kissinger to Donald Trump, No. 47, February 23rd, pg. 22.

[18] English

[19] Andy Zelleke (2020), What Is the End Game of US-China Competition?, at https://thediplomat.com/2020/11/what-is-the-end-game-of-us-china-competition/, on November 03, 2020.

[20] Alex Fang (2020), Biden says US needs to align with democracies after RCEP signing, at https://asia.nikkei.com/Economy/Trade/Biden-says-US-needs-to-align-with-democracies-after-RCEPsigning, on November 17, 2020

[21] Avatkov Vladimir Alekseevich (2018), Neo-Ottomanism as a Key Doctrine of Modern Turkey, at http://www.davidpublisher.com/Public/uploads/Contribute/5fa39ec61c9c3.pdf, on September 2020

[22] Anders Aslund (2020), Putin's Karabakh victory sparks alarm in Ukraine, at https://www.atlanticcouncil.org/blogs/ukrainealert/putins-karabakh-victory-sparks-alarm-in-ukraine/, on 11 November, 2020

[23] Ash Narain Roy and Shimone Jaini (2020), New Latin American left and its complex trajectories, at https://moderndiplomacy.eu/2020/11/12/new-latin-american-left-and-its-complex-trajectories/, on November 12, 2020

[24] Ankara (2018), US, Russia Possess 93 pct of world's nuclear weapons, at https://www.aa.com.tr/en/politics/us-russia-possess-93-pct-of-worlds-nuclear-weapons/1032510, on 2018

[25] Bethany Allen-Ebrahimian (2020), Trump leaves Biden tough choices for his own China playbook, at https://www.axios.com/biden-trump-china-policies-bdc456fc-7591-45ef-acaf-4ec92ccebbb9.html, on Nov 10,2020

[26] Bolivia Population (2020), at https://www.worldometers.info/world-population/bolivia-population/, on December 4, 2020

[27] Eleanor Albert (2020) China Leans Into RCEP Conclusion as Win, at https://thediplomat.com/2020/11/china-leans-into-rcep-conclusion-as-win/, on November 19, 2020.

[28] Eamon Barrett (2020), Why a Biden presidency won't end the U.S.-China trade war, at https://fortune.com/2020/11/09/joe-biden-us-china-trade-war/, on November 9, 2020

[29] Ciara Nugent (2020), The UK Has Officially Left the European Union. But Could Scotland End Up Back in It?, at https://time.com/5778350/will-scotland-rejoin-eu/, on Feb 5, 2020

[30] Caroline Pailliez (2020), Beheading of teacher exposes secular divide in French classrooms, at https://www.reuters.com/article/us-france-security-teachers/beheading-of-teacher-exposes-seculardivide-in-french-classrooms-idUSKBN2772LK, on Octorber 22, 2020

[31] David Gardner (2019), Why Basques and Catalans see independence differently, at https://www.ft.com/content/3ec93f84-a2a1-11e9-974c-ad1c6ab5efd1, on July 12, 2019

[32] David Walsh (2020), Will Belgium's new government delays push the country to split?, at https://www.euronews.com/2020/09/30/will-belgium-s-latest-federal-farce-push-the-country-to-split, on 1 Octorber, 2020

[33] Daniel Boffey (2020), EU faces crisis as Hungary and Poland veto seven-year budget, at https://www.theguardian.com/world/2020/nov/16/eu-hungary-veto-budget-viktor-orban, on 16 Nov 2020

[34] David Dollar, Yiping Huang, Yang Yao (2020), China 2049: Economic Challenges of a Rising Global Power, on 2020

[35] Dave Ross (2020), Why the second wave of the 1918 Spainh flu was so dealy, at https://www.history.com/news/spanish-flu-second-wave-resurgence, on Octorber 2, 2020

[36] Eleanor Albert (2020), China Leans Into RCEP Conclusion as Win, at https://thediplomat.com/2020/11/china-leans-into-rcep-conclusion-as-win/, on November 19, 2020

[37] Ehizuelen Michael Mitchell Omoruyi (2020), China's march towards a moderately well-off society, at http://www.chinadaily.com.cn/a/201803/16/WS5aab21d6a3106e7dcc142020.html 
The Impact of The Pandemic Covid-19 on the State of International Politics and Security

[38] Eugene Chausovsky (2020), Turkey Challenging Russia's Monopoly in the South Caucasus, at https://cgpolicy.org/articles/turkey-challenging-russias-monopoly-in-the-south-caucasus/, on October 7, 2020

[39] Ivana Karásková (2020), Engaging China in 17+1: Time for the ACT Strategy, at https://thediplomat.com/2020/04/engaging-china-in-171-time-for-the-act-strategy/, on April 07, 2020

[40] Hana Sabah and Hamza Hendawi (2020), How Egypt became a leading light of region's electricity sector, at https://www.thenationalnews.com/world/mena/how-egypt-became-a-leading-light-of-region-s-electricitysector-1.1090992, on Oct 9, 2020

[41] Gonul Tol and Rauf Mammadov (2020), Erdogan pulls rabbit out his hat blacksea gas find it all it seems?, at https://www.mei.edu/publications/erdogan-pulls-rabbit-out-his-hat-black-sea-gas-find-it-all-it-seems, on August 25, 2020

[42] Jihan Abdalla (2020), Evo Morales completes triumphant Bolivia return. Now what?, at https://www.aljazeera.com/news/2020/11/11/evo-morales-is-back-in-bolivia-now-what, on 11 Nov 2020

[43] Raja Abdulrahim (2020), Turkish-Backed Syrian Fighters Join Armenian-Azeri Conflict, at https://www.wsj.com/articles/turkish-backed-syrian-fighters-join-armenian-azeri-conflict-11602625885, on Oct. 14,2020

[44] Edam (2020), The Political and Economic Impact of The Coronavirus Pandemic in Turkey, at https://edam.org.tr/en/the-political-and-economic-impact-of-the-coronavirus-pandemic-in-turkey/, on 1 November, 2002

[45] Peter Jones (2020), Open Skies: Can the U.S. withdrawal be delayed?, at https://www.aa.com.tr/en/politics/us-russia-possess-93-pct-of-worlds-nuclear-weapons/1032510

[46] Richard Sokolsky (2020), US-Russian relations in 2030, at https://carnegieendowment.org/2020/06/15/u.s.-russian-relations-in-2030-pub-82056, on June 15, 2020

[47] Yen-Chiang Chang and Shuo Li (2020), China-Japan-Korea free trade agreement and legal issues regarding the construction of the Northeast Asia energy interconnection, at https://aip.scitation.org/doi/10.1063/5.0003919, on July 2020.

[48] Zoey Zhang (2020), what is china's dual circulation strategy and why should foreign investors take note?, at https://www.china-briefing.com/news/what-is-chinas-dual-circulation-strategy-and-why-should-foreigninvestors-take-note/, on September 25, 2020 